\title{
Impaired kidney structure and function in spinal muscular atrophy
}

Flávia C. Nery, PhD, * Jennifer J. Siranosian, BS,* Ivy Rosales, BS, Marc-Olivier Deguise, BS, Amita Sharma, BS, Abdurrahman W. Muhtaseb, BS, Pann Nwe, BS, Alec J. Johnstone, BS, Ren Zhang, BS, Maryam Fatouraei, BS, Natassja Huemer, BS, Christiano R.R. Alves, PhD, Rashmi Kothary, PhD, and Kathryn J. Swoboda, MD

Neurol Genet 2019;5:e353. doi:10.1212/NXG.0000000000000353

\section{Abstract}

\section{Objective}

To determine changes in serum profiles and kidney tissues from patients with spinal muscular atrophy (SMA) type 1 compared with age- and sex-matched controls.

\section{Methods}

In this cohort study, we investigated renal structure and function in infants and children with SMA type 1 in comparison with age- and sex-matched controls.

\section{Results}

Patients with SMA had alterations in serum creatinine, cystatin C, sodium, glucose, and calcium concentrations, granular casts and crystals in urine, and nephrocalcinosis and fibrosis. Nephrotoxicity and polycystic kidney disease PCR arrays revealed multiple differentially expressed genes, and immunoblot analysis showed decreased calcium-sensing receptors and calbindin and increased insulin-like growth factor-binding proteins in kidneys from patients with SMA.

\section{Conclusions}

These findings demonstrate that patients with SMA type 1, in the absence of disease-modifying therapies, frequently manifest impaired renal function as a primary or secondary consequence of their disease. This study provides new insights into systemic contributions to SMA disease pathogenesis and the need to identify coadjuvant therapies.

\author{
Correspondence \\ Dr. Swoboda \\ kswoboda@mgh.harvard.edu
}




\section{Glossary}

ASO = antisense oligonucleotide; CaSR = calcium-sensing receptor; CALB1 = calbindin 1; IGF = insulin-like growth factor; IGFBP = insulin-like growth factor-binding proteins; SMA = spinal muscular atrophy; SMN = survival motor neuron.

Spinal muscular atrophy (SMA), a devastating neuromuscular disease characterized by motor neuron degeneration and progressive muscle atrophy, is a leading genetic cause of infantile death worldwide. SMA is caused by mutations in the Survival Motor Neuron 1 (SMN1) gene that result in reduced functional SMN protein expression. However, a paralog gene, $S M N 2$, undergoes alternative splicing, including the removal of exon 7 , and producing only $\sim 10 \%$ functional SMN protein. ${ }^{1,2}$ The severe infantile variant (SMA type 1) is the most frequent SMA subtype, accounting for more than $50 \%$ of incident cases. Patients with SMA type 1 develop early infantile-onset progressive skeletal, bulbar, and respiratory muscle weakness. By the time such patients present with symptoms, severe denervation has already occurred, and the majority of patients with SMA type 1 die in infancy or childhood. ${ }^{1,3}$

Recent cutting-edge molecular and gene therapies have shown striking clinical benefit when such treatments were started in the presymptomatic or early symptomatic period in infants with SMA type 1. The US Food and Drug Administration approved the use of nusinersen (Spinraza; Biogen, Cambridge, $\mathrm{MA}$ ), a synthetic antisense oligonucleotide (ASO) that modulates premessenger RNA splicing of the SMN2 gene., Clinical trials with nusinersen have demonstrated improvements in morbidity and ventilator-free survival in patients with early infantile-onset SMA. ${ }^{6,7}$ However, increased risk of renal toxicity is listed on the FDA-approved product insert, ${ }^{8}$ and similar therapies have been associated with acute tubular injury. ${ }^{9,10}$ Longitudinal studies for patients treated with nusinersen are still ongoing and will provide additional insights to confirm its long-term efficacy and safety. ${ }^{4}$ In the meantime, other potential therapies for SMA type 1 are under clinical investigation and show promising preliminary results, including the SMN1 gene replacement AVXS-101 (Zolgensma; AveXis, Novartis, Chicago, IL) ${ }^{11,12}$ and the modulator of SMN2 splicing RO7034067 (Risdiplam; Roche, Basel, Switzerland; trial \#NCT02913482). ${ }^{13}$ These emerging therapies, in conjunction with standardized respiratory, orthopedic, and nutritional support, will continue to improve morbidity and survival in even the weakest patients with SMA type 1. Thus, understanding the full spectrum of the impact of SMN deficiency both within and outside of the CNS is critical to the health and well-being of patients with SMA.

Motor neurons are selectively vulnerable to SMN deficiency and subsequently account for the earliest manifestation in SMA clinical disease. However, patients with SMA have decreased levels of SMN protein throughout the whole body, and increasing evidence indicates that SMN deficiency in tissues other than motor neurons may contribute to disease pathogenesis. ${ }^{14-17}$ Systemic administration of an ASO (ASO10-27) that restores SMN expression systemically extended the lifespan of a severe SMA mouse model by 25 -fold, whereas direct intracerebroventricular administration induced a much more modest increase in survival. ${ }^{17}$ However, the only clinically available ASO therapy for patients with SMA is delivered intrathecally and largely limited to the CNS. The drug reaches the systemic circulation via CSF flow dynamics, redistributing to the kidney and other organs to a variable degree before it is excreted in urine. ${ }^{4,5}$ Studies exploring the contribution of peripheral systemic pathology to SMA disease phenotype are limited, and renal studies in SMA have not been performed.

Thus, we investigated serum profiles and kidney tissues from patients with SMA type 1 who died before the availability of proven disease-altering therapies and compared them with age- and sex-matched controls. Participants with SMA type 1 showed low serum creatinine, cystatin $\mathrm{C}(\mathrm{Cys} \mathrm{C})$, and sodium concentrations, high circulating glucose and calcium levels, and granular casts and amorphous crystals in the urine, features that indicate renal tubular dysfunction before death. Participants with SMA displayed (1) medullary nephrocalcinosis and fibrosis, (2) multiple differentially expressed genes and molecular pathways associated with nephrotoxicity and polycystic kidney disease, (3) downregulated calcium-sensing receptor (CaSR) and calbindin 1 (CALB1) proteins, and (4) upregulated insulin-like growth factor-binding proteins 1 (IGFBP1) and 3 (IGFBP3) compared with age- and sexmatched controls. Therefore, we conclude that patients with SMA type 1 have an increased risk of impaired kidney function, more specifically renal tubular dysfunction. This factor needs to be considered from the initial point of diagnosis.

\section{Methods}

\section{Standard protocol approvals, registrations, and patient consents}

Mouse experiments were approved by the Animal Care and Veterinary Services of the University of Ottawa, ON, Canada (protocols \#OHRI-1927 and \#OHRI-1948). This study complies with the guidelines of the International Committee of Medical Journal Editors. The procedures comply with the institutional and national guide for the care and use of laboratory animals. Human studies were approved by the Institutional Ethics Review Board at the University of Utah (protocol \#8751).

\section{Mice}

This study was approved by the Animal Care and Veterinary Services of the University of Ottawa, ON, Canada (protocols \#OHRI-1927 and \#OHRI-1948). Smn ${ }^{2 \mathrm{~B} /-}$ mice were obtained 
as previously described ${ }^{18}$ and housed at the Animal Facility of University of Ottawa in accordance with the Canadian Council on Animal Care. Samples were collected from symptomatic $\mathrm{Smn}^{2 \mathrm{~B} /-}$ mice at postnatal day 19. Mouse blood was collected following decapitation using either Microvette CB300 K2 EDTA (Sarstedt, cat\# 16.444.100) coated with EDTA for plasma extraction or Microvette CB300 Z (Sarstedt, cat\# 16.440.100). Blood was spun for 5 minutes at $10,000 g$ to obtain serum and $2,000 \mathrm{~g}$ to obtain plasma at room temperature. Plasma was analyzed for creatinine, blood urea nitrogen (BUN), albumin, calcium, and phosphorus at a veterinary reference laboratory using commercially available biochemical assays (Beckman-Coulter, Inc, Brea, CA) on an automated clinical chemistry analyzer platform (Beckman-Coulter AU680; Beckman-Coulter, Inc). Sodium, chloride, and potassium were determined using ion-selective electrodes (Beckman-Coulter) on the same platform. Kidney tissues were collected for Western blot analysis.

\section{Human experiments}

This cohort study includes a total of 13 pediatric participants with SMA type 1 who died during the course of their disease and 13 age- and sex-matched pediatric controls from the NIH NeuroBioBank. Written informed parental consent was obtained for all participants with SMA under the Institutional Ethics Review Board at the University of Utah (protocol \#8751) and Massachusetts General Hospital (protocol \#2016P000469). No participants with SMA received either disease-modifying therapies nusinersen or AVXS-101 gene therapy. Tissues from controls were obtained from the NIH NeuroBioBank's Brain and Tissue repository at the University of Maryland, Baltimore. Comprehensive clinical data were available for all participants with SMA, and premortem clinical laboratory data from medical records were available for 12 participants with SMA. Kidney samples were obtained during a rapid autopsy protocol in 12 participants with SMA and 13 controls. Sufficient tissue was available in 4 age- and sexmatched SMA and controls for RNA (SMA \#177, 272, 251, and 195; controls: \#5883, 5282, 5564, and 5180) and protein (SMA \#272, \#251, \#195, and \#101, and controls: \#5387, \#5564, \#5282, and \#5883) extraction and analysis.

\section{SMN1 and SMN2 copy numbers}

$S M N 1$ and SMN2 copy numbers were determined by droplet digital PCR using the Bio-Rad QX-200 system (Bio-Rad, Hercules, CA). Each sample was amplified separately to measure $S M N 1$ or SMN2 copies relative to the number of CFTR copies. A competitive oligo with a $3^{\prime}$ phosphate was used to increase probe specificity. ${ }^{19}$ SMN1 was detected with SMN-Ex7-FP 5' AATGCTTTTTAACATCCATATAAAGCT, SMN-Ex7-RP 5'CCTTAATTTA AGGAATGTGAGCACC, SMN1-LNA probe $\mathrm{FAM}-\mathrm{A}+\mathrm{G}+\mathrm{GGTT}+\mathrm{T}+\mathrm{c}+\mathrm{AGAC}$ and competitive SMN1 oligo ATTTTCCTTACAGGGTTTtAGACAAAATCAAAAGAPHO. SMN2 was detected with the same primers as SMN1 and using SMN2-LNA probe FAM-A+G+GGTT+T+T+AGAC and competitive SMN2 oligo ATTTTCCTTACAGGG
TTTcAGACAAAATCAAAAGA-PHO. The SMN1 and SMN2 probes are located at the $\mathrm{C} / \mathrm{T}$ base difference in SMN exon 7 . Each reaction was multiplexed with a primer/probe set to detect exon 14 of CFTR as a 2-copy gene control using FP-CFTR 5' AGAGAGAAGGCTGTCCTTAGT, RP-CFTR 5' GAGTGTGTCATCAGGTTCAGG, and HEXTTCTGAGCAGGGAGAGGCGATACT probe. Copy numbers were determined by dividing the number of $S M N 1$ or $S M N 2$ copies by the number of CFTR copies for each sample.

\section{Biochemical analysis}

CysC concentrations were determined using Luminex $\mathrm{xMAP}^{\circledR}$ technology (Myriad RBM, Austin, TX) on existing frozen serum samples. Circulating creatinine, BUN, calcium, phosphorous, sodium, chloride, potassium, glucose, and C-reactive protein, granular casts and amorphous crystals in the urine, and generalized aminoaciduria analyses were available from premortem clinical laboratory data in the Project Cure SMA Longitudinal Population Data Repository (Massachusetts General Hospital IRB protocol \#2016P000469).

\section{Histology}

Paraffin-embedded kidney tissues were cut at a thickness of 5$\mu \mathrm{m}$ and stained with hematoxylin and eosin, periodic acidSchiff, Masson trichrome, Alizarin red, von Kossa, and Prussian blue according to standard histologic protocols. Sections were examined by an experienced renal pathologist (I.R.) blinded for sample IDs. For immunohistochemistry, paraffin-embedded tissues were cut at a thickness of $5 \mu \mathrm{m}$ on glass slides and incubated at $60^{\circ} \mathrm{C}$ for 30 minutes, followed by deparaffinization in xylene and rehydration in graded alcohol into water. Antigen retrieval was performed by boiling the slides in $10 \mathrm{mM}$ sodium citrate buffer $(\mathrm{pH}=6.0)$ for 30 minutes. Endogenous peroxidase activity was quenched with Dual Endogenous Enzyme Block (DAKO, Agilent, CA) for 5 minutes. Tissue sections were incubated with 1:500 dilution of CaSR mouse monoclonal antibody (Novus 5C10, ADD) or 1:5,000 dilution of CALB1 rabbit polyclonal antibody (Sigma-Aldrich HPA023099) or 1: 100 dilution of AQP3 (Atlas Antibodies HPA014924) in 1\% TBS/BSA at $4^{\circ} \mathrm{C}$ inside a humidified chamber overnight. After washing, slides were incubated with Envision Dual Link System Polymer HRP (DAKO) for 30 minutes at room temperature. After washing, the DAB+ reagent (DAKO) was added with monitoring for 5-10 minutes. After washing, counterstain was performed using Harris-type hematoxylin. Slides were briefly dehydrated and then mounted with Histomount solution (Life Technology, Grand Island, NY). Immunohistochemical analyses were performed according to standard protocols on 4-m sections using the Vector $\mathrm{ABC}$ Reagent kit and developed with DAB substrate (Vector Laboratories, Burlingame, CA). Kidney slides were also double stained for CD3 (1:400 Dako A0452)/ CD68 (1:800 Dako M0814) markers in the autostainer.

\section{PCR array}

Total RNA was extracted from frozen kidney samples using TRIzol reagent (Thermo Fisher Scientific, Waltham, MA). All the samples had a $280 / 260$ ratio $\geq 1.9$. Complementary DNA 
Table 1 Serum biochemical profiles in spinal muscular atrophy type 1 participants

\begin{tabular}{|c|c|c|c|c|c|c|c|c|c|c|c|c|c|}
\hline $\begin{array}{l}\text { Patient } \\
\text { ID no. }\end{array}$ & $\begin{array}{l}\text { Age at } \\
\text { death }\end{array}$ & Creatinine & Cystatin C & BUN & Calcium & Phosphorus & Sodium & Chloride & Potassium & Glucose & $\begin{array}{l}\text { C-reactive } \\
\text { protein }\end{array}$ & $\begin{array}{l}\text { Granular casts and/or } \\
\text { amorphous crystals }\end{array}$ & $\begin{array}{l}\text { Generalized } \\
\text { aminoaciduria }\end{array}$ \\
\hline \multicolumn{2}{|c|}{ Normal ranges: } & $\begin{array}{l}0.23-0.61 \\
\mathrm{mg} / \mathrm{dL}\end{array}$ & $\begin{array}{l}0.51-1.10 \\
\mathrm{mg} / \mathrm{L}\end{array}$ & $\begin{array}{l}5-17 \\
\mathrm{mg} / \mathrm{dL}\end{array}$ & $\begin{array}{l}8.7-9.8 \\
\mathrm{mg} / \mathrm{dL}\end{array}$ & $\begin{array}{l}3.7-7.4 \\
\mathrm{mg} / \mathrm{dL}\end{array}$ & $\begin{array}{l}\text { 137-146 } \\
\mathrm{mmol} / \mathrm{L}\end{array}$ & $\begin{array}{l}\text { 98-109 } \\
\mathrm{mmol} / \mathrm{L}\end{array}$ & $\begin{array}{l}3.4-4.7 \\
\mathrm{mmol} / \mathrm{L}\end{array}$ & $\begin{array}{l}60-108 \\
\mathrm{mg} / \mathrm{dL}\end{array}$ & $\begin{array}{l}<0.8 \\
\mathrm{mg} / \mathrm{dL}\end{array}$ & Urine results & \\
\hline 101 & 10.2 & $<0.05-0.4$ & 0.35 & $3.0-17$ & $7.5-10.2$ & $4.3-5.5$ & $133-142$ & $102-115$ & 3.9 & $82-142$ & $<0.7-3.2$ & Present & Present \\
\hline 187 & 5.1 & $0.05-0.28$ & $0.54-0.65$ & $2.0-13$ & $6.7-10.8$ & $2.0-6.4$ & 123-158 & $79-124$ & $1.7-7.0$ & $65-332$ & 6.2 & Absent & Present \\
\hline $7 \dagger$ & 4 & 0.2 & N.t. & $2.0-10$ & $8.1-10.3$ & $1.7-6.0$ & $134-143$ & $97-114$ & $3.3-7.0$ & $66-358$ & $<0.8$ & Present & N.t. \\
\hline 196 & 3.8 & $0.08-0.24$ & $0.57-0.66$ & $4.0-23$ & $8.1-10.6$ & $2.5-5.7$ & 133-159 & $91-114$ & $1.7-6.9$ & $71-168$ & $<0.5-8.1$ & Present & Present \\
\hline 195 & 2.96 & $0.10-0.30$ & $0.38-0.43$ & $3.0-13$ & $8.9-10.5$ & $5.8-6.1$ & $128-140$ & $97-112$ & $3.7-7.2$ & $71-135$ & $0.5-1.2$ & Present & Normal \\
\hline 217 & 2.75 & $0.12-0.32$ & 0.61 & $5.0-25$ & $8.3-11.6$ & $2.4-5.6$ & $133-163$ & $95-125$ & $3.2-6.0$ & $70-143$ & $0.3-1.3$ & Present & N.t. \\
\hline 206 & 2.34 & $0.15-0.34$ & $0.47-0.75$ & $7.0-17$ & $8.9-11.6$ & N.t. & 131-139 & $102-108$ & $3.5-5.6$ & $73-105$ & $<0.5$ & N.t. & N.t. \\
\hline 403 & 2.3 & 0.06 & N.t. & 5.0 & 8.3 & N.t. & N.t. & N.t. & N.t. & 449 & N.t. & N.t. & N.t. \\
\hline 353 & 1.65 & N.t. & N.t. & $5.0-8.0$ & $8.9-10.6$ & N.t. & N.t. & N.t. & $3.2-5.4$ & 116 & N.t. & N.t. & N.t. \\
\hline 177 & 1.38 & $0.11-0.7$ & $0.54-0.69$ & $3.0-15$ & $8.4-10.4$ & $3.9-7.7$ & $132-146$ & $97-114$ & $3.0-5.4$ & $70-209$ & $0.2-0.5$ & Present & Present \\
\hline 251 & 1.2 & $0.14-0.66$ & $0.35-0.83$ & $5.0-19$ & $8.4-10.1$ & N.t. & 135-139 & $95-108$ & $3.8-4.3$ & $70-97$ & N.t. & Present & N.t. \\
\hline 351 & 0.56 & $0.21-0.34$ & 0.96 & $2.0-16$ & 8.9-10.6 & $3.9-5.1$ & $137-143$ & $103-112$ & $2.6-5.5$ & $73-218$ & N.t. & Present & N.t. \\
\hline \multicolumn{2}{|c|}{ Lowest value } & 11/11 (100\%) & 4/9 (44\%) & $8 / 12(67 \%)$ & 7/12 (58\%) & $5 / 8(63 \%)$ & $9 / 10(90 \%)$ & $7 / 10(70 \%)$ & 7/11 (64\%) & $0 / 12(0 \%)$ & $0 / 8(0 \%)$ & $8 / 9$ (89\%) & $4 / 5(80 \%)$ \\
\hline \multicolumn{2}{|c|}{ Highest value } & 2/11 (18\%) & $0 / 9(0 \%)$ & $3 / 12(25 \%)$ & 11/12 (92\%) & 1/8 (13\%) & $3 / 10(30 \%)$ & $8 / 10(80 \%)$ & 9/11 (82\%) & 10/12 (83\%) & $5 / 8(63 \%)$ & & \\
\hline
\end{tabular}

Abbreviations: BUN = blood urea nitrogen; N.t. = not tested. 
was generated from $500 \mathrm{ng}$ of purified RNA using the RT2 First Strand Kit (Qiagen, Venlo, the Netherlands) protocol or $300 \mathrm{ng}$ for SuperScript IV VILO (11766050; ThermoFisher Scientific). The Nephrotoxicity and Polycystic Kidney Disease RT ${ }^{2}$ Profiler PCR Arrays (PAHS-094Z and PAHS-168Z; Qiagen) were performed, and each messenger RNA (mRNA) gene expression was calculated relative to the average of 5 housekeeping genes in the arrays accordingly to the manufacture instructions.

\section{Western blot}

Protein was extracted from frozen kidney samples using RIPA lysis buffer (Cell Signaling Technology, Danvers, MA). Samples were sonicated and centrifuged at $10,000 \mathrm{rpm}$ for 10 minutes at $4^{\circ} \mathrm{C}$. Protein concentrations were determined using the Bradford assay (Bio-Rad). Protein samples (30 $\mu \mathrm{g})$ were run on a NuPAGE 12\% Bis-Tris Protein Gel (NP0342Box, Invitrogen by Thermo Fisher Scientific) electrophoresis and transferred to a nitrocellulose membrane. Membranes were incubated with Odyssey blocking buffer (Li-Cor 927-40,000) diluted 1:1 in Tris-buffered saline buffer. REVERT Total Protein Stain (Li-Cor 926-11,010) was used for loading control. Primary antibodies were incubated overnight at $4^{\circ} \mathrm{C}$ to probe for SMN (BD Transduction, San Jose, CA, Catalog 610647, Dilution 1:2,000, monoclonal), IGFBP1 (Santa Cruz, Dallas, TX, Catalog c-55474, Dilution 1:1,000, monoclonal), IGFBP3 (Abcam, Cambridge, UK, Catalog ab77635, Dilution 1:1,000, goat polyclonal), IGF-1 (Abcam, Catalog ab9572, Dilution 1: 500, rabbit polyclonal), IGFALS (Thermo Fisher Scientific,
Catalog PA5-59252, Dilution 1:1,000, rabbit polyclonal), CaSR (Novus, Denver, CO, Catalog NB120-19347SS, Dilution 1: 500, monoclonal), CALB1 (Sigma, Saint Louis, MO, Catalog HPA023099, Dilution 1:750, rabbit polyclonal), and $\alpha$-tubulin (Cell Signaling Technology, Catalog 3873S, Clone DM1A, Dilution 1:2,000, monoclonal). Secondary antibodies were IRDye 680RD Donkey anti-Mouse IgG (Li-COR, Catalog 92568,072, Dilution 1:5,000), IRDye 680RD Donkey anti-Goat IgG (Li-COR, Lincoln, NE, Catalog 925-68,074, Dilution 1: 5,000), IRDye 800CW Donkey anti-Mouse IgG (Li-COR, Catalog 925-32,212, Dilution 1:10,000), IRDye 800CW Donkey anti-Rabbit IgG (Li-COR, Catalog 925-32,213, Dilution 1: 10,000), and IRDye 800CW Donkey anti-Goat IgG (Li-COR, Catalog 925-32,214, Dilution 1:2,000). Membranes were imaged using the Odyssey CLx (Li-COR). Blots were quantified using Image J and normalized by $\boldsymbol{\alpha}$-tubulin.

\section{Statistical analysis}

Data are presented as mean \pm standard error of the mean with dots as individual values. Sample size is indicated in the figure legends. Statistical analyses were performed using GraphPad Prism 7 software (GraphPad Software, Inc). Unpaired 2-tailed Student $t$ tests were used to compare groups. Statistical significance was defined as $p<0.05$.

\section{Data availability}

All data relevant to this study are contained within the article.

Figure 1 Kidney histopathology in patients with SMA type 1

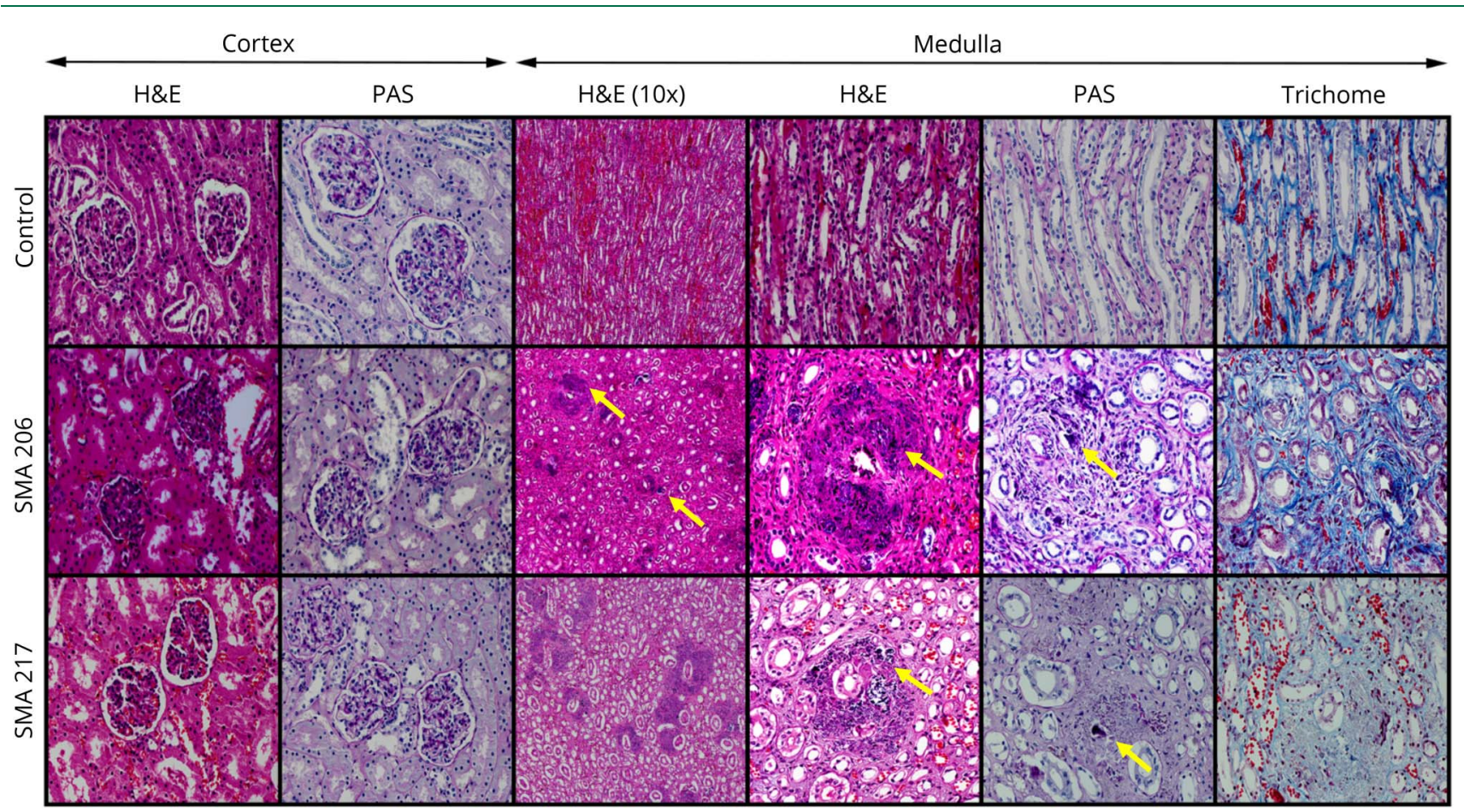

Sections from the kidneys of SMA cases show medullary calcifications (yellow arrows, H\&E and PAS) along collecting ducts. Medullary interstitial fibrosis is also present (trichrome). Representative images were taken at $100 \times$ (indicated as $10 \times$ objective) and 400× magnifications. H\&E = hematoxylin and eosin; PAS = periodic acid-Schiff; SMA = spinal muscular atrophy. 


\section{Results}

To determine whether renal function is affected in a model of SMA, we first evaluated serum creatinine, BUN, albumin, calcium, phosphorus, sodium, chloride, and potassium in $S m n^{2 B /-}$ mice. $S m n^{2 B /-}$ mice have reduced SMN protein content through the whole body, including in the kidney (figure S1, links.lww.com/NXG/A174), exhibiting a classic SMA phenotype and a short lifespan (<30 days). ${ }^{18,20} \mathrm{Smn}^{2 \mathrm{~B} /-}$ mice had reduced circulating creatinine, BUN, albumin, calcium, and chloride at symptomatic age postnatal day 19 (table S1). These initial observations suggest that renal abnormalities are present in an intermediate mouse model of the disease.

We further investigated available renal tissues and laboratory data from a cohort of 13 participants with SMA type 1 who were followed longitudinally and died in infancy or childhood due to complications of SMA and compared them with ageand sex-matched controls (tables S2 and S3, links.lww.com/ NXG/A174). All participants with SMA were confirmed to have homozygous deletion of SMN1 and 2 SMN2 copies (table S2), whereas all controls had at least 1 SMN1 copy (table S3). During longitudinal follow-up, laboratory studies were obtained in the clinical care setting, including circulating creatinine, BUN, calcium, phosphorus, sodium, chloride, potassium, glucose, and C-reactive protein. In addition, we evaluated circulating $\mathrm{CysC}$, a cysteine protease inhibitor produced by all nucleated cells and freely filtered by the glomerulus. By comparing the blood test results with reference values, most of the patients in our study consistently had values out of the expected range in all these analytes (table 1 and table S4).

We investigated kidneys from 12 participants with SMA who underwent comprehensive rapid research autopsy with a postmortem interval time ranging from 1 to 20 hours in all but 1 subject (table S2, links.lww.com/NXG/A174). The absolute mass of kidneys from SMA type 1 and controls was similar (figure S2). We found several histopathologic changes in kidney tissues from participants with SMA type 1 without corresponding abnormalities in controls (figures 1 and 2, figure S3, table 2, and table S5). Participants with SMA type 1 showed varying degrees of tubular injury characterized by loss of brush borders, flattened epithelium with detachment, and occasional protein casts. Interstitial fibrosis and tubular atrophy were absent to minimal. Occasional intratubular calcification was present in 2 of 12 participants with SMA (figure 1A and table 2, IDs \#206 and 217). The glomeruli showed rare,

Figure 2 Medullary calcifications in patients with SMA type 1

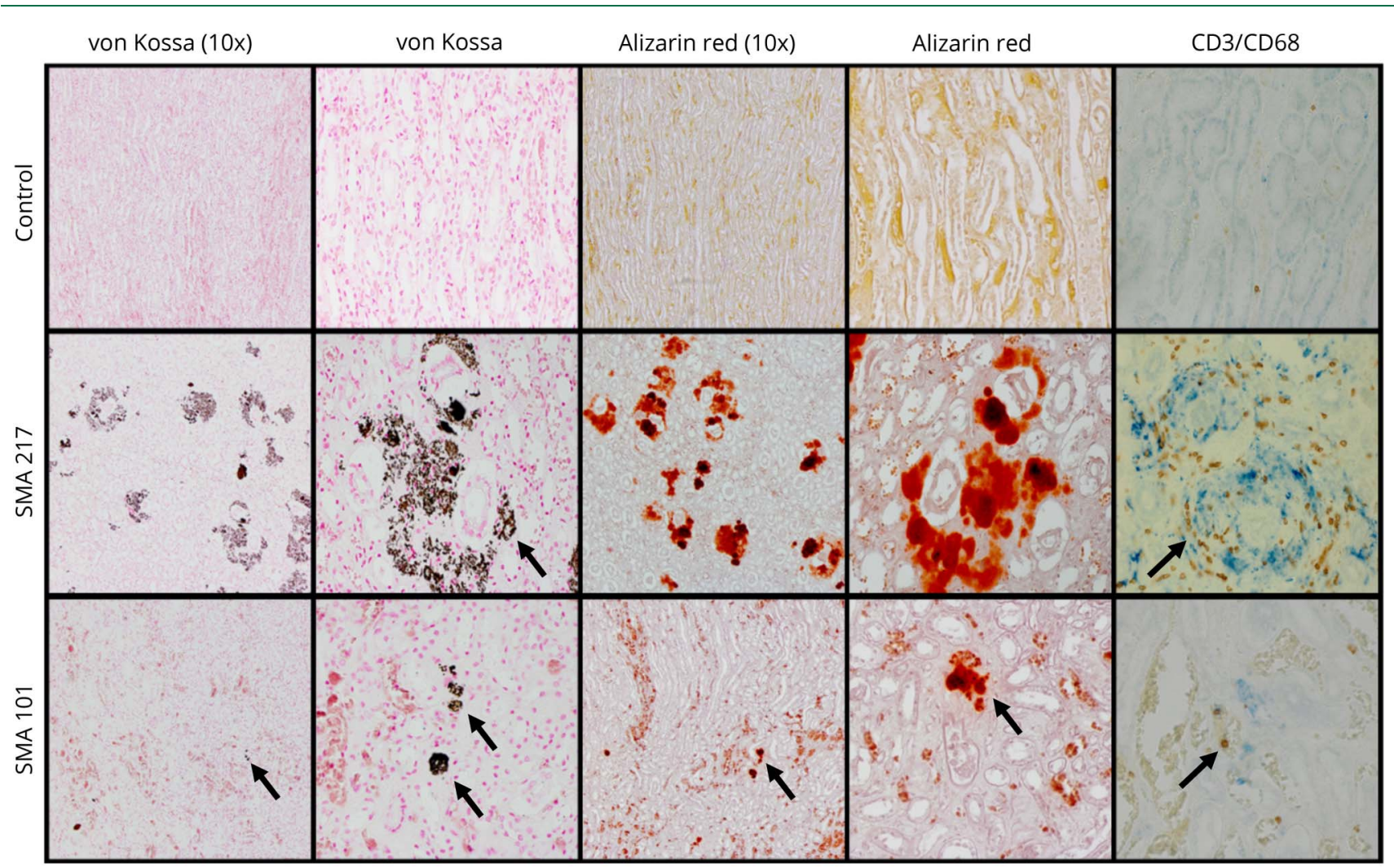

The medullary calcifications (black arrows) are positive for von Kossa and Alizarin red stains. Immunohistochemical studies show CD3 ${ }^{+}$(brown) and CD68 ${ }^{+}$ (blue) cells along calcifications black (arrows). Representative images were taken at $100 \times$ (indicated as $10 \times$ objective) and $400 \times$ magnifications. SMA = spinal muscular atrophy. 
Table 2 Pathologic findings in spinal muscular atrophy type 1 kidneys

\section{Cortex}

\section{no. Pathologic findings in kidneys at autopsy}

101 Tubules showed normal size, pyknotic nuclei, acute tubular necrosis, and calcifications in the cortex and medulla

\section{Interstitium}

(n)

Rare mesangia

hypercellularity; rare adhesions renal collecting system

196 Small focal nephrocalcinosis in the right kidney

Focal mesangial hypercellularity/rare adhesions

195 No reported abnormalities

None

217 Scattered calcifications in the kidney

Rare mesangial

hypercellularity; rare

adhesions and $<5 \%$ global sclerosis

206 Multifocal calcifications in the renal medulla with surrounding inflammation and fibrosis. Focal hyaline hypercellularity; rare casts, dilated tubules in the medulla are associated with areas of dystrophic calcification and

hypercellularity; rare

Tubular changes

Calcification Inflammation Mild to moderate

$<5 \%$

None

Mild Non

None

None

None

Mild to moderate; None occasional protein

casts

sclerosis

accumulation of macrophages and multinucleated cells. Pale renal medullary pyramids bilaterally

403 Acute tubular congestion of kidneys

Diffuse mesangial hypercellularity; rare hypercellularity; rare

sclerosis

353 Acute passive congestion; microcalcifications

Focal mesangial

hypercellularity; rare

adhesions and $<5 \%$ globa sclerosis

Mild

None

None

\section{Medulla}

Interstitium

Alizarin von CD3/

$<5 \%$ Focal Pos Pos Pos

$<5 \%$

(1)

N.t.

t.

N.t.

Milo

Mild Foc

None None

None

$<5 \%$

$<5 \%$

Focal

Focal Pos

Pos Pos

Focal,
intratubular

None

Non

None Neg

M

Mild Focal

Focal,
intratubular

$<1 \%$

$<1 \% \quad<10 \% \quad 60 \%$

Pos Pos Pos

\begin{tabular}{|c|c|c|c|c|c|c|c|c|c|c|c|}
\hline 177 & Scattered nephrocalcinosis & None & None & None & None & None & None & None & N.t. & Neg & N.t. \\
\hline 251 & No reported abnormalities & None & None & None & None & None & None & None & N.t. & N.t. & N.t. \\
\hline 351 & No reported abnormalities & None & None & None & $<5 \%$ & None & $<5 \%$ & $\begin{array}{l}\text { Focal } \\
<5 \%\end{array}$ & N.t. & Pos & N.t. \\
\hline 272 & No reported abnormalities & None & Mild & None & None & None & $<1 \%$ & None & N.t. & Neg & N.t. \\
\hline
\end{tabular}

Abbreviations: Pos = positive; Neg = negative; N.t. = not tested. 
focal mesangial hypercellularity and adhesions in 6 participants with SMA (figures 1 and 2 and figure S3, IDs \#101, 196, $217,206,403$, and 353). Approximately 50\% of SMA kidneys showed tubular injury, medullary calcinosis, and fibrosis (table 2). Medullary calcification surrounding collecting ducts associated with interstitial fibrosis was prominent in 2 participants (figure 1, A and B, IDs \#206 and 217). Alizarin red and von Kossa stains confirmed medullary calcium phosphate deposits. Positive staining for T-cell and macrophage markers (CD3 and CD68) around calcification foci indicates an inflammatory response (figure 1B). Overall, pathologic abnormalities in the kidney were present in two-thirds of participants with SMA type 1 in our cohort. Although findings suggesting acute tubular injury could be confounded by terminal events, the tubulointerstitial lesions, including nephrocalcinosis and interstitial fibrosis, are indicative of chronic renal dysfunction. Future studies will be important to determine whether impaired kidney function is a primary consequence of reduced SMN protein, a secondary consequence of muscle atrophy and bone disease, or more likely a combination of both.

Furthermore, we were interested in determining the molecular mechanisms associated with renal dysfunction. Nephrotoxicity and polycystic kidney disease PCR arrays revealed multiple differentially expressed genes in kidneys from participants with SMA type 1 compared with controls (figure 2, A and B). Each PCR array targeted 84 genes

Figure 3 Changes in genes involved in calcium reabsorption in the kidney from SMA participants

A. Nephrotoxicity array

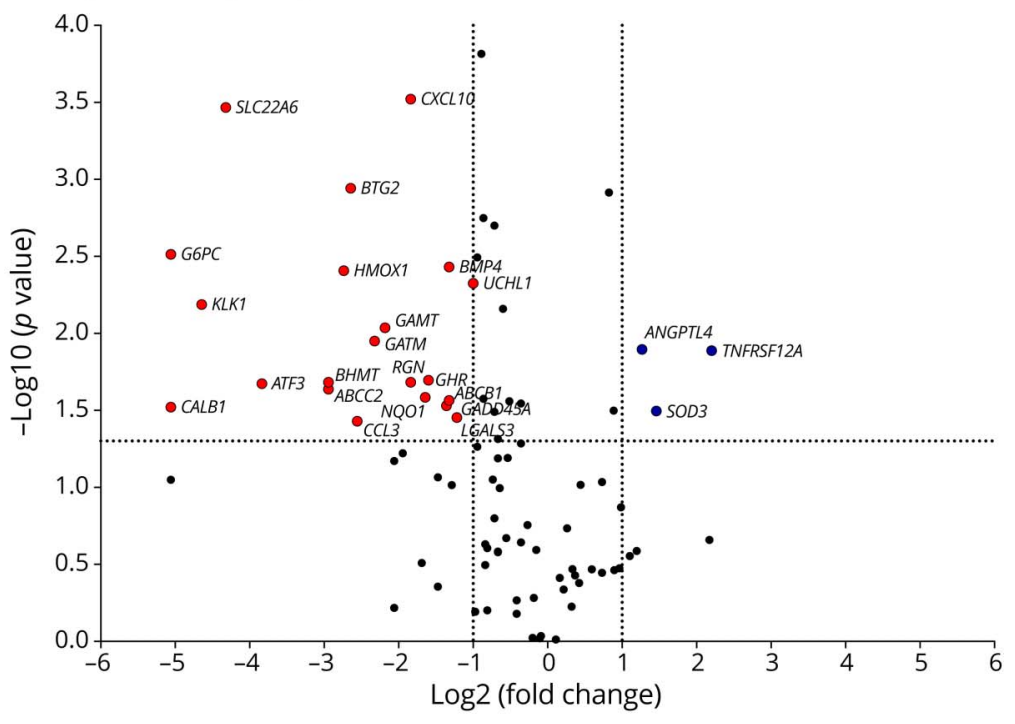

B. Polycystic kidney disease array

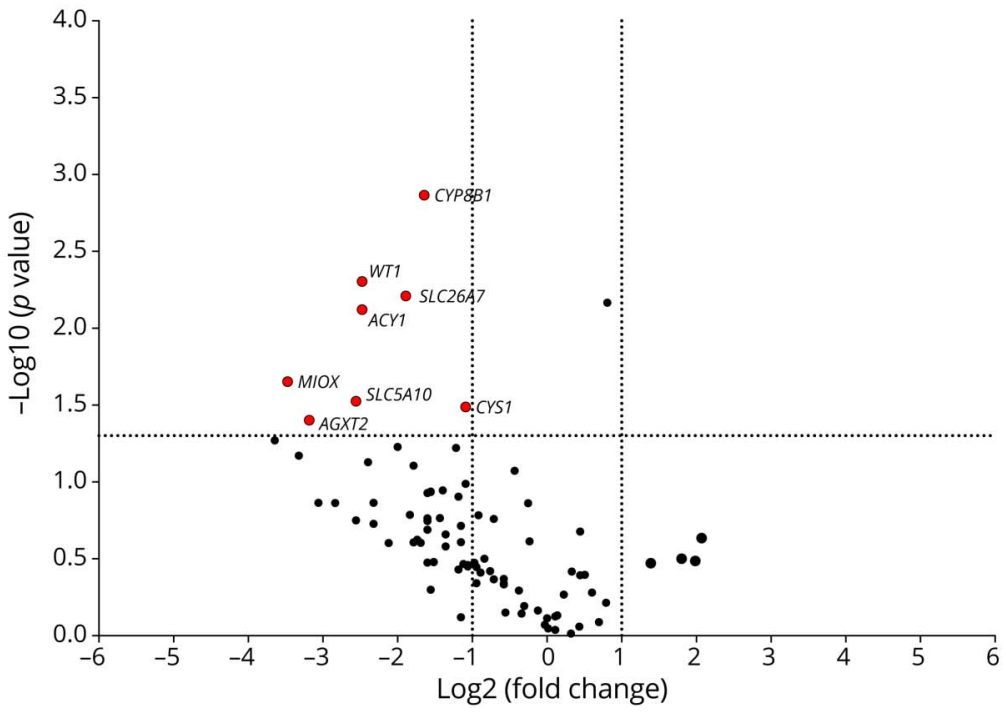

Volcano plots derived from (A) Nephrotoxicity $\mathrm{RT}^{2}$ Profiler PCR Array and (B) Polycystic Kidney Disease RT ${ }^{2}$ Profiler PCR Array in kidney samples from SMA and controls. Upregulated and downregulated genes are indicated in red and blue, respectively $(n=3-4)$. Unpaired 2-tailed Student $t$ tests were used to compare groups. SMA = spinal muscular atrophy. 
previously characterized as biomarkers associated with either kidney toxicity or cystic renal disease. We found 25 differentially expressed genes in the nephrotoxicity array (figure S4A, links.lww.com/NXG/A174, and table S6) and 8 in the polycystic kidney disease array (figure S4B and table S7, figures 3 and 4). These genes are involved in calcium signaling, apoptosis, cell proliferation, metal ion binding, glucose metabolism, oxidative stress, and kidney transporters signaling. Moreover, immunohistochemistry (figure 2, C and D) and immunoblot (figure 2, E and F) analysis demonstrated that participants with SMA type 1 had decreased CaSR and CALB1 protein expression.

It has been previously demonstrated that insulin-like growth factor 1 (IGF-1) is dysregulated in severely affected SMA mice. ${ }^{17}$ Given that IGF-1 signaling plays a role in the maintenance of normal renal function, ${ }^{21}$ we further evaluated IGF-1 signaling in renal tissues from SMA type 1 and controls. Participants with SMA type 1 had normal IGF-1 protein content, but increased levels of IGFBP1 and IGFBP3 (figure 2, E and F).

\section{Discussion}

Most of the patients in our study consistently had values out of the expected range in several blood analytes. We believe that many of these abnormalities are an expected consequence of severe generalized muscle atrophy and bone disease. For example, low creatinine concentrations in these participants were expected because creatinine is a product of creatine metabolism, and creatine is mainly present in muscle. ${ }^{22}$ Importantly, analysis of urine sediment revealed granular casts and/or amorphous crystals and generalized aminoaciduria in the majority of participants with SMA type 1 (table 1). These elements being found in urine are associated with acute and chronic kidney injury with potential calcium oxalate deposition within the renal tubules. This process may lead to obstruction of the urine flow in the tubules while the intratubular crystals develop an inflammatory reaction with the renal interstitium and promote acute kidney dysfunction. ${ }^{23,24}$ Overall, the clinical laboratory data in these participants strongly suggest that the majority had impaired kidney

Figure 4 Increased IGFBPs in kidney from SMA participants

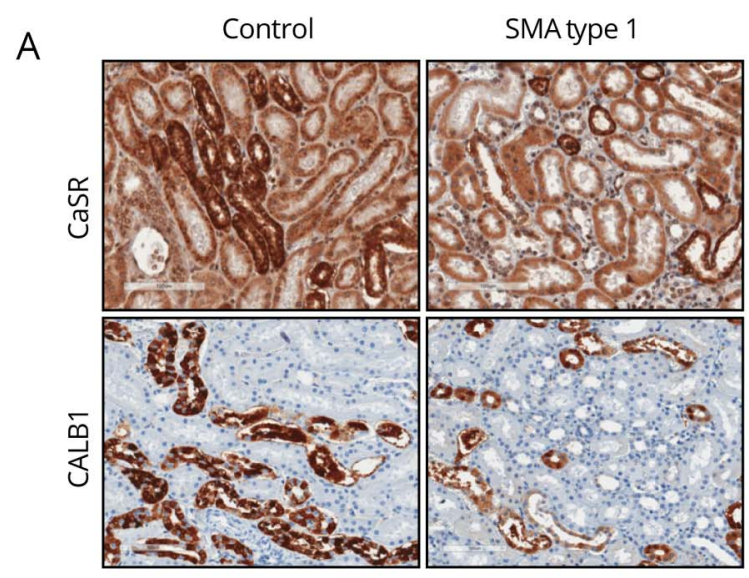

B

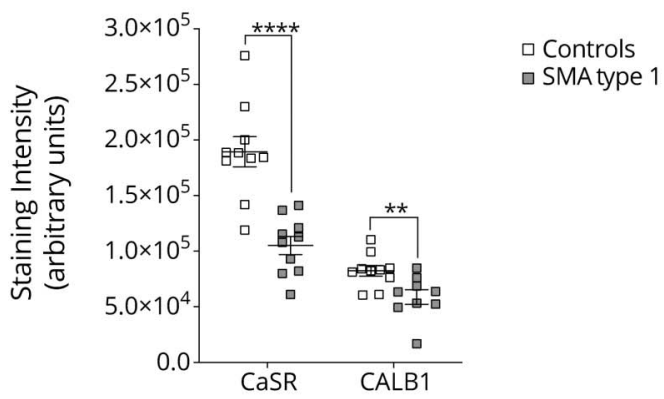

C
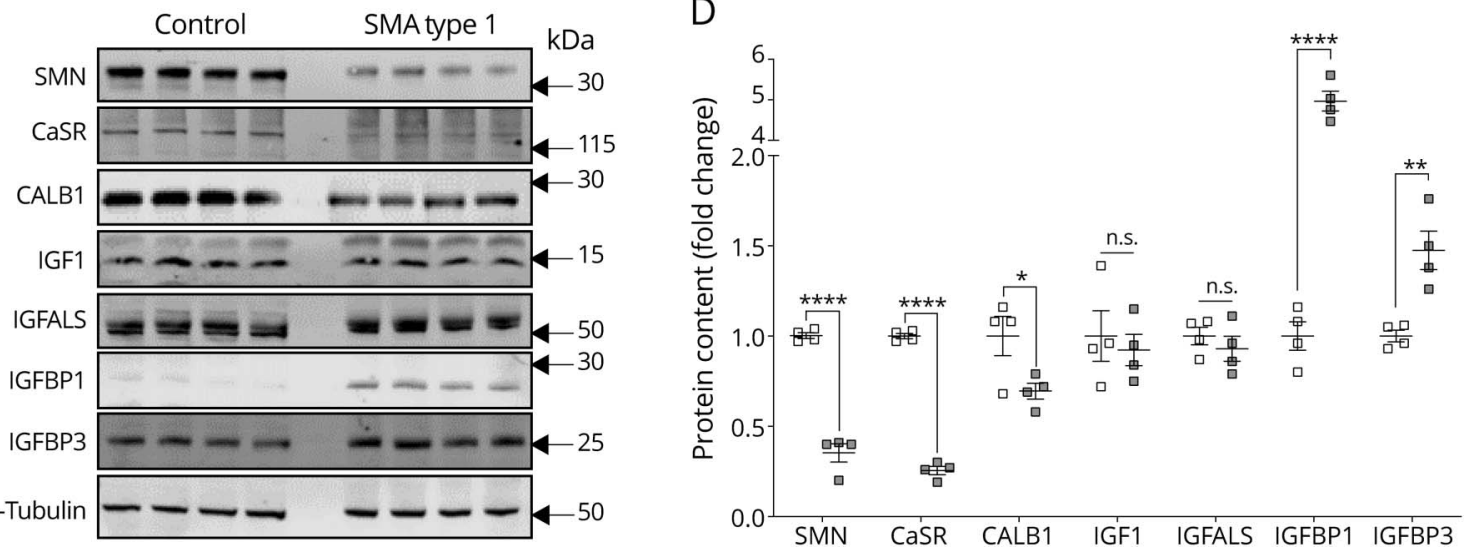

(A) Representative immunohistochemistry (magnification 100x) and (B) quantification of staining intensity for CaSR and CALB1 in kidney samples from SMA and controls $(n=9-10)$. (C) Representative immunoblot and (D) quantification of protein content in kidney samples from SMA $(n=4)$ and controls $(n=4)$. Data

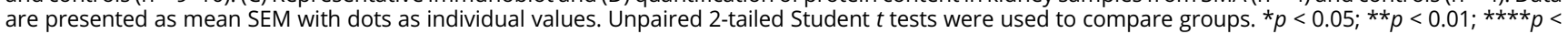
0.0001 . CALB1 = calbindin 1; CaSR = calcium-sensing receptor; IGF = insulin-like growth factor; IGFBP = insulin-like growth factor binding proteins; SMA = spinal muscular atrophy. 
function before death, with features indicative of renal tubular dysfunction.

Participants with SMA type 1 had decreased CaSR and CALB1 protein expression. CaSR and CALB1 play critical anticalcification roles. CaSR acts as a sensitive detector of extracellular calcium and regulates parathyroid hormone activity, protecting against calcium phosphate precipitation. ${ }^{25,26}$ CALB1 regulates calcium reabsorption, and models of kidney dysfunction show downregulated CALB $1 .{ }^{27}$ Altogether, these changes in the expression of key molecules and proteins are consistent with renal function abnormalities as indicated by premortem clinical laboratory testing.

Participants with SMA type 1 had increased levels of IGFBP1 and IGFBP3. IGF signaling is complex, and IGFBPs have an important role in this signaling by enhancing or inhibiting IGF-1. IGFBP1 also affects cell growth and apoptosis. ${ }^{21,28}$ Transgenic mice with increased Igfbpl expression demonstrate reduced number of nephrons and glomerulosclerosis, ${ }^{29}$ whereas those with Igfbp 3 overexpression show hypoplastic kidneys. ${ }^{30}$ Kidneys in early-stage diabetic rats show increased IGFBP1 expression, ${ }^{31}$ and increased IGFBP3 protease activity correlates with the degree of albuminuria in patients with diabetic nephropathy. ${ }^{32}$ Thus, increased local expression of IGFBPs supports the concept of impaired kidney function in participants with SMA.

The precise mechanism by which kidney function is impaired in patients with SMA type I is not fully understood. We believe that changes in kidney structure, gene, and protein expression are in large part a consequence of severe generalized muscle atrophy, immobility, and dysregulation of bone metabolism resulting in secondary medullary calcification and renal tubular dysfunction. However, given the numerous functions of the SMN protein, SMN deficiency could also contribute to changes in gene expression through direct mechanisms. SMN protein plays an integral role in the spliceosomal assembly and processing of pre-mRNA species in all cells. ${ }^{33}$ For example, SMN depletion has been demonstrated to cause intron retention, triggering a global DNA damage and stress response. ${ }^{34}$ In future studies, additional approaches, including in vitro studies, are necessary for determining whether SMN has a primary contribution to the gene expression profile in developing nephrons.

The present study has important clinical implications. Patients with SMA type 1 are living longer due to recent advances in SMA therapeutics, and impaired kidney function is likely to be a significant comorbidity. To help improve longterm survival and well-being of patients with SMA, it is important to think ahead to provide therapeutic avenues that can positively modulate renal function.

\section{Acknowledgment}

Financial support was provided to K.J.S. from NIH NINDS R21-NS108015 and Cure SMA. R.K. was supported by Cure
SMA/Families of SMA Canada; Muscular Dystrophy Association (USA) (\#575466); and Canadian Institutes of Health Research (CIHR) (\#PJT-156379). M.-O.D. was supported by a Frederick Banting and Charles Best CIHR Doctoral Research Award. N.H. was supported by CAPES, Brazil. The authors thank Vicky L. McGovern and Arthur H.M. Burghes for technical support and scientific discussion and Patricia Della Pelle for technical support in histology. Control tissues were obtained from the NIH NeuroBioBank's Brain and Tissue repository at the University of Maryland, Baltimore. They are very grateful to all the SMA families who participated in this study.

\section{Study funding}

No targeted funding reported.

\section{Disclosure}

Disclosures available: Neurology.org/NG.

\section{Publication history}

Received by Neurology: Genetics April 10, 2019. Accepted in final form June 25, 2019.

\section{Appendix Authors}

\begin{tabular}{|c|c|c|c|}
\hline Name & Location & Role & Contribution \\
\hline Flávia C. Nery & $\begin{array}{l}\text { Massachusetts } \\
\text { General } \\
\text { Hospital, } \\
\text { Boston, MA }\end{array}$ & Author & $\begin{array}{l}\text { Directed the research } \\
\text { project and designed } \\
\text { experiments; performed } \\
\text { experiments; collected } \\
\text { clinical data; analyzed the } \\
\text { data; wrote the } \\
\text { manuscript; participated } \\
\text { in the data interpretation, } \\
\text { and reviewed and } \\
\text { approved the final } \\
\text { manuscript. }\end{array}$ \\
\hline
\end{tabular}

\begin{tabular}{|c|c|c|c|}
\hline $\begin{array}{l}\text { Jennifer J. } \\
\text { Siranosian }\end{array}$ & $\begin{array}{l}\text { Massachusetts } \\
\text { General } \\
\text { Hospital, } \\
\text { Boston, MA }\end{array}$ & Author & $\begin{array}{l}\text { Performed experiments; } \\
\text { collected clinical data; } \\
\text { analyzed the data; wrote } \\
\text { the manuscript; } \\
\text { participated in the data } \\
\text { interpretation; and } \\
\text { reviewed and approved } \\
\text { the final manuscript. }\end{array}$ \\
\hline Ivy Rosales & $\begin{array}{l}\text { Massachusetts } \\
\text { General } \\
\text { Hospital, } \\
\text { Boston, MA }\end{array}$ & Author & $\begin{array}{l}\text { Performed experiments; } \\
\text { analyzed the data; } \\
\text { participated in the data } \\
\text { interpretation; and } \\
\text { reviewed and approved } \\
\text { the final manuscript. }\end{array}$ \\
\hline $\begin{array}{l}\text { Marc-Olivier } \\
\text { Deguise }\end{array}$ & $\begin{array}{l}\text { University of } \\
\text { Ottawa, } \\
\text { Canada }\end{array}$ & Author & $\begin{array}{l}\text { Performed mouse } \\
\text { experiments; } \\
\text { participated in the data } \\
\text { interpretation; and } \\
\text { reviewed and approved } \\
\text { the final manuscript. }\end{array}$ \\
\hline Amita Sharma & $\begin{array}{l}\text { Massachusetts } \\
\text { General } \\
\text { Hospital, } \\
\text { Boston, MA }\end{array}$ & Author & $\begin{array}{l}\text { Performed experiments; } \\
\text { collected clinical data; } \\
\text { participated in the data } \\
\text { interpretation; and } \\
\text { reviewed and approved } \\
\text { the final manuscript. }\end{array}$ \\
\hline
\end{tabular}


Appendix (continued)

\begin{tabular}{|c|c|c|c|}
\hline Name & Location & Role & Contribution \\
\hline $\begin{array}{l}\text { Abdurrahman } \\
\text { W. Muhtaseb }\end{array}$ & $\begin{array}{l}\text { Massachusetts } \\
\text { General } \\
\text { Hospital, } \\
\text { Boston, MA }\end{array}$ & Author & $\begin{array}{l}\text { Performed experiments; } \\
\text { participated in the data } \\
\text { interpretation; and } \\
\text { reviewed and approved } \\
\text { the final manuscript. }\end{array}$ \\
\hline Pann Nwe & $\begin{array}{l}\text { Massachusetts } \\
\text { General } \\
\text { Hospital, } \\
\text { Boston, MA }\end{array}$ & Author & $\begin{array}{l}\text { Performed experiments; } \\
\text { collected clinical data; } \\
\text { participated in the data } \\
\text { interpretation; and } \\
\text { reviewed and approved } \\
\text { the final manuscript. }\end{array}$ \\
\hline $\begin{array}{l}\text { Alec J. } \\
\text { Johnstone }\end{array}$ & $\begin{array}{l}\text { Massachusetts } \\
\text { General } \\
\text { Hospital, } \\
\text { Boston, MA }\end{array}$ & Author & $\begin{array}{l}\text { Performed experiments; } \\
\text { collected clinical data; } \\
\text { participated in the data } \\
\text { interpretation; and } \\
\text { reviewed and approved } \\
\text { the final manuscript. }\end{array}$ \\
\hline
\end{tabular}

Ren Zhang

Massachusetts Author Performed experiments; General collected clinical data; Hospital, participated in the data Boston, MA interpretation; and reviewed and approved the final manuscript.

Maryam Massachusetts Author Performed experiments;

Fatouraei General Author $\quad \begin{aligned} & \text { Performed experiments: } \\ & \text { participated in the data }\end{aligned}$ Hospital, interpretation; and Boston, MA reviewed and approved the final manuscript.

\begin{tabular}{|c|c|c|c|}
\hline $\begin{array}{l}\text { Natassja } \\
\text { Huemer }\end{array}$ & $\begin{array}{l}\text { Massachusetts } \\
\text { General } \\
\text { Hospital, } \\
\text { Boston, MA }\end{array}$ & Author & $\begin{array}{l}\text { Performed experiments; } \\
\text { participated in the data } \\
\text { interpretation; and } \\
\text { reviewed and approved } \\
\text { the final manuscript. }\end{array}$ \\
\hline
\end{tabular}

Christiano R.R. Massachusetts Author Analyzed the data; wrote
Alves General Author Analyzed the da Hospital, Boston, MA participated in the data interpretation; and reviewed and approved the final manuscript.

\begin{tabular}{|c|c|c|c|}
\hline $\begin{array}{l}\text { Rashmi } \\
\text { Kothary }\end{array}$ & $\begin{array}{l}\text { University of } \\
\text { Ottawa, } \\
\text { Canada }\end{array}$ & Author & $\begin{array}{l}\text { Performed mouse } \\
\text { experiments; } \\
\text { participated in the data } \\
\text { interpretation; and } \\
\text { reviewed and approved } \\
\text { the final manuscript. }\end{array}$ \\
\hline
\end{tabular}

\begin{tabular}{|c|c|c|c|}
\hline $\begin{array}{l}\text { Kathryn J. } \\
\text { Swoboda }\end{array}$ & $\begin{array}{l}\text { Massachusetts } \\
\text { General } \\
\text { Hospital, } \\
\text { Boston, MA }\end{array}$ & Author & $\begin{array}{l}\text { Directed the research } \\
\text { project and designed } \\
\text { experiments; collected } \\
\text { clinical data; wrote the } \\
\text { manuscript; participated } \\
\text { in the data interpretation; } \\
\text { and reviewed and } \\
\text { approved the final } \\
\text { manuscript. }\end{array}$ \\
\hline
\end{tabular}

\section{References}

1. Groen EJN, Talbot K, Gillingwater TH. Advances in therapy for spinal muscular atrophy: promises and challenges. Nat Rev Neurol 2018;14:214-224.

2. Faravelli I, Nizzardo M, Comi GP, Corti S. Spinal muscular atrophy-recent therapeutic advances for an old challenge. Nat Rev Neurol 2015;11:351-359.
3. Thomas NH, Dubowitz V. The natural history of type I (severe) spinal muscular atrophy. Neuromuscul Disord 1994;4:497-502.

4. Corey DR. Nusinersen, an antisense oligonucleotide drug for spinal muscular atrophy. Nat Neurosci 2017;20:497-499.

5. Wood MJA, Talbot K, Bowerman M. Spinal muscular atrophy: antisense oligonucleotide therapy opens the door to an integrated therapeutic landscape. Hum Mol Genet 2017;26:R151-R159.

6. Finkel RS, Mercuri E, Darras BT, et al. Nusinersen versus sham control in infantileonset spinal muscular atrophy. N Engl J Med 2017;377:1723-1732.

7. Finkel RS, Chiriboga CA, Vajsar J, et al. Treatment of infantile-onset spinal muscular atrophy with nusinersen: a phase 2, open-label, dose-escalation study. Lancet 2016; 388:3017-3026

8. Spinraza (Nusinersen) Injection [package insert]. Cambridge, MA: Biogen Inc.; 2016.

9. Khvorova A, Watts JK. The chemical evolution of oligonucleotide therapies of clinical utility. Nat Biotechnol 2017;35:238-248.

10. Van Poelgeest EP, Swart RM, Betjes MGH, et al. Acute kidney injury during therapy with an antisense oligonucleotide directed against PCSK9. Am J Kidney Dis2013;62: 796-800.

11. Mendell J, Al-Zaidy S, Shell R, et al. AVXS-101 phase 1 gene therapy clinical trial in SMA type 1: end-of-study event free survival and achievement of developmental milestones. Neuromuscul Disord 2017;27(Suppl 2):S208.

12. Mendell JR, Al-Zaidy S, Shell R, et al. Single-dose gene-replacement therapy for spinal muscular atrophy. N Engl J Med 2017;377:1713-1722.

13. Ratni H, Ebeling M, Baird J, et al. Discovery of risdiplam, a selective survival of motor neuron-2 (SMN2) gene splicing modifier for the treatment of spinal muscular atrophy (SMA). J Med Chem 2018;61:6501-6517.

14. Rudnik-Schöneborn S, Heller R, Berg C, et al. Congenital heart disease is a feature of severe infantile spinal muscular atrophy. J Med Genet 2008;45:635-638.

15. Simone C, Ramirez A, Bucchia M, et al. Is spinal muscular atrophy a disease of the motor neurons only: pathogenesis and therapeutic implications? Cell Mol Life Sci 2016;73:1003-1020.

16. Deguise MO, Kothary R. New insights into SMA pathogenesis: immune dysfunction and neuroinflammation. Ann Clin Transl Neurol 2017;4:522-530.

17. Hua Y, Sahashi K, Rigo F, et al. Peripheral SMN restoration is essential for long-term rescue of a severe spinal muscular atrophy mouse model. Nature 2011;478:123-126.

18. Deguise MO, De Repentigny Y, McFall E, Auclair N, Sad S, Kothary R. Immune dysregulation may contribute to disease pathogenesis in spinal muscular atrophy mice. Hum Mol Genet 2017;26:801-819.

19. Anhuf D, Eggermann T, Rudnik-Schöneborn S, Zerres K. Determination of SMN1 and SMN2 copy number using TaqMan ${ }^{\text {TM }}$ technology. Hum Mutat 2003;22:74-78.

20. Eshraghi M, McFall E, Gibeault S, Kothary R. Effect of genetic background on the phenotype of the $\operatorname{Smn} 2^{B /-}$ mouse model of spinal muscular atrophy. Hum Mol Genet 2016;25:4494-4506.

21. Oh Y. The insulin-like growth factor system in chronic kidney disease: pathophysiology and therapeutic opportunities. Kidney Res Clin Pract 2012;31:26-37.

22. Hijikata Y, Hashizume A, Yamada S, et al. Biomarker-based analysis of preclinical progression in spinal and bulbar muscular atrophy. Neurology 2018;90:e1501-e1509.

23. Mulay SR, Shi C, Ma X, Anders HJ. Novel insights into crystal-induced kidney injury. Kidney Dis (Basel) 2018;4:49-57.

24. Luciano RL, Perazella MA. Crystalline-induced kidney disease: a case for urine microscopy. Clin Kidney J 2015;8:131-136.

25. Vezzoli G, Terranegra A, Rainone F, et al. Calcium-sensing receptor and calcium kidney stones. J Transl Med 2011;9:201.

26. Ba J, Brown D, Friedman PA. Calcium-sensing receptor regulation of PTH-inhibitable proximal tubule phosphate transport. Am J Physiol Physiol 2003;285:F1233-F1243.

27. Iida T, Fujinaka H, Xu B, et al. Decreased urinary calbindin 1 levels in proteinuric rats and humans with distal nephron segment injuries. Clin Exp Nephrol 2014;18: $432-443$.

28. Jones J, Gockerman A, Busby W, et al. Insulin-like growth factor binding protein stimulates cell migration and binds to the alphasbetal integrin by means of its ArgGly-Asp sequence. EMBO J 1993;90:10553-10557.

29. Doublier S, Seurin D, Fouqueray B, et al. Glomerulosclerosis in mice transgenic for human insulin-like growth factor-binding protein-1. Kidney Int 2000;57:2299-2307.

30. Modric T, Silha JV, Shi Z, et al. Phenotypic manifestations of insulin-like growth factor-binding protein-3 overexpression in transgenic mice. Endocrinology 2001;142: 1958-1967.

31. Flyvbjerg A, Kessler U, Dorka B, Funk B, Ørskov H, Kiess W. Transient increase in renal insulin-like growth factor binding proteins during initial kidney hypertrophy in experimental diabetes in rats. Diabetologia 1992;35:589-593.

32. Shinada M, Akdeniz A, Panagiotopoulos S, Jerums G, Bach LA. Proteolysis of insulinlike growth factor-binding protein-3 is increased in urine from patients with diabetic nephropathy. J Clin Endocrinol Metab 2000;85:1163-1169.

33. Swoboda KJ. Romancing the spliceosome to fight spinal muscular atrophy. N Engl J Med 2014;371:1752-1754

34. Jangi M, Fleet C, Cullen P, et al. SMN deficiency in severe models of spinal muscular atrophy causes widespread intron retention and DNA damage. Proc Natl Acad Sci 2017;114:E2354-E2356. 


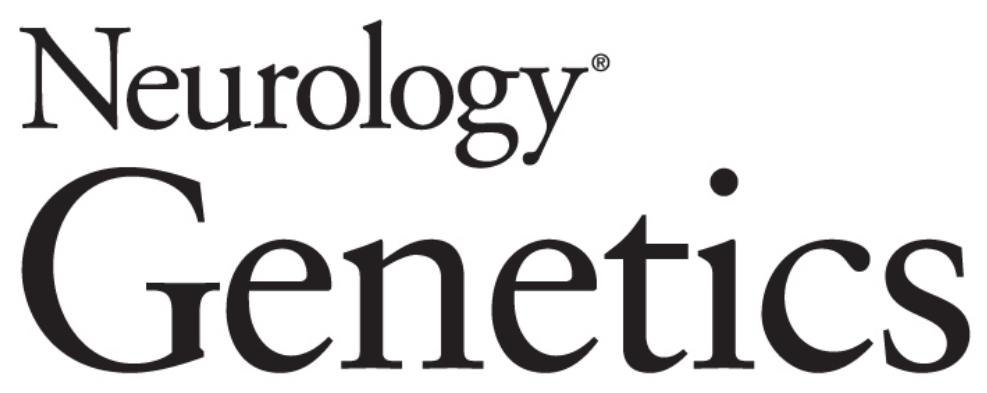

\section{Impaired kidney structure and function in spinal muscular atrophy Flávia C. Nery, Jennifer J. Siranosian, Ivy Rosales, et al. Neurol Genet 2019;5; DOI 10.1212/NXG.0000000000000353}

This information is current as of August 12, 2019

\section{Updated Information \& Services}

\section{References}

Citations

Subspecialty Collections

Permissions \& Licensing

Reprints including high resolution figures, can be found at: http://ng.neurology.org/content/5/5/e353.full.html

This article cites 33 articles, 1 of which you can access for free at: http://ng.neurology.org/content/5/5/e353.full.html\#\#ref-list-1

This article has been cited by 2 HighWire-hosted articles: http://ng.neurology.org/content/5/5/e353.full.html\#\#otherarticles

This article, along with others on similar topics, appears in the following collection(s):

All Medical/Systemic disease

http://ng.neurology.org//cgi/collection/all_medical_systemic_disease All Neuromuscular Disease

http://ng.neurology.org//cgi/collection/all_neuromuscular_disease Muscle disease

http://ng.neurology.org//cgi/collection/muscle_disease

Information about reproducing this article in parts (figures,tables) or in its entirety can be found online at:

http://ng.neurology.org/misc/about.xhtml\#permissions

Information about ordering reprints can be found online: http://ng.neurology.org/misc/addir.xhtml\#reprintsus

Neurol Genet is an official journal of the American Academy of Neurology. Published since April 2015, it is an open-access, online-only, continuous publication journal. Copyright Copyright (C) 2019 The Author(s). Published by Wolters Kluwer Health, Inc. on behalf of the American Academy of Neurology.. All rights reserved. Online ISSN: 2376-7839.

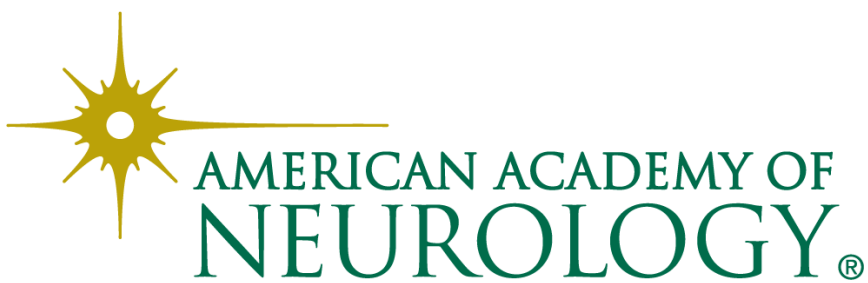

